\title{
Comparison of Antifungal Susceptibilities in Candidemic Newborns According to Their Body Weights
}

\author{
Kandidemik Yenidoğanlarm Vücut Ağırlıklarma Göre \\ Antifungal İlaç Duyarlklarmmn Değerlendirilmesi \\ Alişan YILDIRAN, Nurşen BELET, Murat GÜNAYDIN, ${ }^{1}$ Şükrü KÜÇÜKÖDÜK \\ Departments of Pediatrics, and ${ }^{1}$ Microbiology, Medical Faculty of Ondokuz Mayıs University, Samsun
}

Submitted / Başvuru tarihi: 08.12.2008 Accepted / Kabul tarihi: 22.01.2009

\begin{abstract}
Objectives: There is a lack of data comparing antifungal susceptibilities of Candida isolates in candidemic newborns weighing $\leq 1500 \mathrm{~g}$ versus those weighing $>1500 \mathrm{~g}$. This study aims to compare antifungal susceptibilities of newborns according to their birth weights.
\end{abstract}

Patients and Methods: All candidemic newborns assessed retrospectively. Candida species were identified using the API 20C AUX system. In vitro susceptibility of isolates for fluconazole, ketoconazole, itraconazole and amphotericine B were determined using the E-test and the broth macrodilution method. Clinical backgrounds of patients were also examined.

Results: Of 2700 newborns admitted to our neonatal intensive care unit in years 2001-2002, 375 (14\%) were $<1500 \mathrm{~g}$. Forty five $(1.7 \%)$ of all infants developed candidemia. Nineteen were in Group 1, 26 were in Group 2. As possible risk factors, mean length of ventilation and catheter days were greater in Group 2. All Candida species yielded from Group 1 were more susceptible to antifungal drugs. Minimum inhibitory concentration (MIC) 50 and 90 values of non-albicans strains were almost always higher in Group 2.

Conclusion: In this study, Candida species were more susceptible in the newborns weighing $<1500 \mathrm{~g}$. We believe this situation is related to less number of possible risk factors for the newborns weighing $<1500 \mathrm{~g}$.

Key words: Antifungal; candidemia; comparison; newborn; susceptibility.
Amaç: Ağırığı 1500 g'ın altındaki ve üstündeki bebeklerin kandida suşlarının antifungal duyarlıkları konusunda yeterli bilgi yoktur. Bu çalışmanın amacı kandidemik yenidoğanlardaki antifungal ilaç duyarlıklarının doğum ağırlıklarına göre değerlendirilmesidir.

Hastalar ve Yöntemler: Tüm kandidemik yenidoğanlar retrospektif olarak değerlendirildi. Kandida türleri API 20C AUX system kullanılarak belirlendi. Flukonazol, ketokonazol, itrakonazol ve amfoterisin B için in vitro duyarlıklar E-test ve broth macrodilution metodu ile ölçüldü. Hastaların klinik özellikleri kaydedildi.

Bulgular: Yenidoğan yoğun bakım ünitemize 20012002 yıllarında başvuran 2700 yenidoğandan $375^{\prime} \mathrm{i}$ (\%14) 1500 gramın altında idi. Tüm bebeklerin 45 'inde (\%1.7) kandidemi gelişti. Bunlar doğum ağırlıklarına göre sınıflandırıldı (Grup $1 \leq 1500$ g; Grup $2>1500$ g). Grup 1'de 19 olgu, Grup 2'de 26 olgu kaydedildi. Olası risk faktörlerinden ortalama mekanik ventilasyon süresi ve kateter süresi Grup 2'de daha fazla idi. Grup 1 'deki üretilen kandida türlerinin antifungal ilaçlara daha duyarlı olduğu belirlendi. Grup 2'deki nonalbikans türlerin minimum inhibitör konsantrasyon (MIC)-50 ve 90 değerleri daha yüksekti.

Sonuç: Bu çalışmada 1500 g'ın altındaki bebeklerdeki kandida türlerinin antifungal ilaçlara daha duyarlı olduğu bulundu. Bu durum $1500 \mathrm{~g}$ altındaki bebeklerdeki olası risk faktörlerinin daha az olmasından kaynaklanmış olabilir.

Anahtar sözcükler: Antifungal; kandidemi; karşılaştırma; yenidoğan; duyarlık.

Correspondence (iletişim adresi): Dr. Alişan Yıldıran. Ondokuz Mayıs Üniversitesi Tıp Fakültesi, Çocuk Sağığı ve Hastalıkları Anabilim Dalı, 55139 Samsun. Tel: 0362 - 3121919 /2514 Fax (Faks): 0362 - 4576041 e-mail (e-posta): yildiran@omu.edu.tr

๑ Trakya Üniversitesi Tip Fakültesi Dergisi. Ekin Tıbbi Yayıncılık tarafından basılmıştır. Her hakkı saklıdır.

๑ ( Medical Journal of Trakya University. Published by Ekin Medical Publishing. All rights reserved. 
Candida species colonize up to $60 \%$ of neonates weighing less than $1500 \mathrm{~g}$ during their first month in the neonatal intensive care unit (NICU). Such colonization may progress to invasive fungal infection in up to $20 \%$ of these infants. These babies are at risk for invasive fungal infection because of their immature immune systems and the invasive supportive care which they require. ${ }^{[1]}$ Treatment of fungal infections is relatively easy because azole derivatives (such as fluconazole, ketoconazole and itraconazole) are very potent. Candida albicans (C. albicans) is one of the most common fungi encountered. Some fungi (such as C. glabrata and C. krusei) are relatively resistant to the azole derivatives. ${ }^{[2]}$ A PubMed search using the keywords candidemic newborn, comparison or candidemia, newborn and susceptibility revealed that there is a lack of data comparing susceptibility patterns of Candida isolates in candidemic newborns according to their birth-weight. We aimed to compare the causative organisms of candidemia and their susceptibility to antifungal drugs in candidemic newborns weighing $\leq 1500 \mathrm{~g}$ versus those weighing $>1500 \mathrm{~g}$ in our NICU with their clinical backgrounds.

\section{PATIENTS AND METHODS}

In our study, candidemia was defined as either Candida spp. recovered from peripheral blood culture at least twice with an interval of more than 24 hours, regardless of clinical manifestation, or Candida spp. recovered from peripheral blood culture once with clinical symptoms suggesting infection, or Candida spp. recovered from sites other than the bloodstream. ${ }^{[3]}$ If candidemia episodes were at least 2 months apart and if there were at least three documented negative blood cultures between each episode in a single infant, these episodes were considered as distinct. Eradication of candidemia was defined as no Candida spp. isolated from at least two consecutive blood cultures after candidemia developed and symptoms of infection disappeared..$^{[2,4]}$

In this retrospective study, all babies admitted to the neonatal intensive care unit of Ondokuz Mayis University in years 2001-2002 were eligible. Our NICU is the biggest high-risk perinatal center in the Black Sea region of Turkey, with approximately 1500 hospitalizations per year. Patients were eligible for enrollment in the study if blood cultures yielded Candida spp. and clinical and/or laboratory evidence suggested infection or if repeated cultures of the same Candida spp. were obtained from one or more sites. ${ }^{[3]}$ According to our medical records, there were 45 candidemic newborns. Babies were divided into two groups; Group $1 ; \leq 1500 \mathrm{~g}$ and $>1500 \mathrm{~g}$, Group 2; >1500 g.

We collected data on birth weight, gestational age (GA), and the length of mechanical ventilated, catheter duration in days, systemic steroid using and antibiotics using as possible risk factors.

\section{Blood Cultures}

Blood cultures were obtained from peripheral veins (if indwelling vascular catheters were present, cultures were drawn from another site) when neonatal sepsis was suspected. Criteria for neonatal sepsis included clinical symptoms and signs of infection, positive inflammatory markers (C-reactive protein $>1.0 \mathrm{mg} / \mathrm{dl}$ ), and/or abnormal hematologic values (leukopenia $<5000 / \mathrm{mm}^{3}$, leukocytosis $>15000 / \mathrm{mm}^{3}$, thrombocytopenia $<150000 /$ $\mathrm{mm}^{3}$, immature to mature leukocyte ratio $>0.2$, immature to total neutrophil ratio $>0.16) .{ }^{[4]}$

Blood samples $(0.5-1 \mathrm{ml})$ were inoculated into aerobic and anaerobic Bactec blood culture media (9050, Blood Culture System, Becton Dickinson, USA) and processed according to standard microbiologic techniques. ${ }^{[3]}$ Also, the cultures of urine, tracheal aspirates, and cerebrospinal fluid (CSF) were taken. For the urine cultures, the perineum of each infant was swabbed with povidone iodine and rinsed with sterile water before urine bag application. For tracheal aspirate cultures, endotracheal tube aspirates were collected in the sterile traps during suctioning by the nursing staff. Cerebrospinal fluid was obtained when clinically indicated. ${ }^{[4]}$

\section{Identification and Antifungal Susceptibility Test of Candida Species}

Each Candida species was identified using the API 20C AUX system (API, Biomerieux, France). In vitro susceptibility of isolates to a panel of four antifungal agents (fluconazole, ketoconazole, itraconazole and conventional amphotericin B) were determined using E-test (AB BIODISK, Solna, Sweden) and the broth macrodilution method. The E-test was performed according to the manufacturer's recommendations and the broth macrodilution susceptibility test was applied according to National Committee for Clinical Laboratory Standards (NCCLS) guidelines. ${ }^{[7,8]}$ Quality control was ensured by testing the strains of C. albicans ATCC 90028, C. albicans 26555, C. parapsilosis ATCC 22019, and C. krusei ATCC 6258 .

Isolates were classified as resistant to fluconazole if the minimum inhibitory concentration (MIC) was $\geq 64 \mu \mathrm{g} / \mathrm{ml}$, as resistant to itraconazole if the MIC was $\geq 1 \mu \mathrm{g} / \mathrm{ml}$, and as resistant to ketoconazole if the MIC was $\geq 8 \mu \mathrm{g} / \mathrm{ml} .^{[9,10]}$ Isolates with an M27 amphotericin B MIC of $\geq 1 \mu \mathrm{g} / \mathrm{ml}$ is considered likely resistant to $\mathrm{CAB} .{ }^{[3]}$

\section{Statistical Analysis}

All clinical data and laboratory results were recorded on a daily basis. Mann-Whitney-U test was used to compare patient demographics and possible risk factors of both groups. Chi-square tests were used for comparisons of gestational ages. $\mathrm{P}$ value of $<0.05$ indicated significance. 
Table 1. Patient demographics and possible risk factors of both groups.

\begin{tabular}{lrr}
\hline & $\begin{array}{c}\text { Group 1 } \\
\mathrm{n}( \pm \text { SD })\end{array}$ & $\begin{array}{r}\text { Group 2 } \\
\mathrm{n}( \pm \mathrm{SD})\end{array}$ \\
\hline Gestational age (wk) $^{* *}$ & $29( \pm 3.5)$ & $37( \pm 3.7)$ \\
Birth weight $(\mathrm{g})^{* *}$ & $1130( \pm 45)$ & $2713( \pm 146)$ \\
Candidemia-day (d) ${ }^{* *}$ & $18( \pm 3.3)$ & $18.1( \pm 2.5)$ \\
Possible risk factors & & \\
\hline \multicolumn{1}{l}{ Length of mechanic ventilation (d) } & $8( \pm 2)$ & $19( \pm 6)^{*}$ \\
$\quad$ Catheterization-time (d) & $19( \pm 4)$ & $30( \pm 6)^{*}$ \\
$\quad$ Systemic steroid [n (\%)] & $0(0)$ & $3(11)$ \\
Antibiotics (per patient d) & 2.9 & 2.4 \\
\hline
\end{tabular}

${ }^{*} \mathrm{p}<0.05$ ** wk: week; g: gram; d: day;

\section{RESULTS}

\section{Clinical Presentation}

Of 2700 newborns admitted to our NICU in years 2001-2002, $45(1.7 \%)$ infants developed candidemia. $375(14 \%)$ newborns' birth weight were $\leq 1500 \mathrm{~g}$ (Group 1 ), others' $(86 \%)$ birth weight were $>1500$ g (Group 2). Primary diagnoses of patients in Group 1 were early sepsis in $3(15 \%)$, respiratory distress syndrome (RDS) in $14(73 \%)$, and being small for the gestational age in 2 $(12 \%)$ infants. Primary diagnoses of patients in Group 2 were RDS in $8(31 \%)$, early sepsis in $6(23 \%)$, late sepsis in $1(4 \%)$, hypoxic ischemic encephalopathy in $4(14 \%)$, ichtyosis (collodion baby) in $2(8 \%)$, cholestasis in 2 $(8 \%)$, congenital heart disease in $1(4 \%)$, omphalocel in $1(4 \%)$ and congenital pneumonia in $1(4 \%)$ infant. Patient demographics and some possible risk factors in both groups are summarized in Table 1. Candidemic days were similar for both groups but length of ventilation and catheter days were significantly more in Group 2.

\section{Laboratory Findings}

Fifteen newborns had C. albicans, 3 had C. tropicalis and 1 had C. Guiermondii in Group 1. Twenty-two newborns had C. albicans, 3 had C. parapsilosis and 1 had C. tropicalis in Group 2.
Candida spp. were isolated in the urine of 6 (2 vs. 4) infants and in tracheal aspirate samples of 1 ( 0 vs. 1 ) infant. No Candida was grown on CSF samples. No distinct candidemia episode was observed in any infants.

All Candida isolates yielded from Group 1 were more susceptible to antifungal drugs. Minimum inhibitory concentration $_{50}$ and $\mathrm{MIC}_{90}$ values of non-albicans strains were almost always higher in Group 2 (Table 2).

\section{DISCUSSION}

We determined that $C$. albicans was the most common Candida species in both groups. According to Lopez Sastre et al. ${ }^{[4]}$, very-low-birth-weight (VLBW) infants $(\leq 1500 \mathrm{~g})$ showed a significantly higher incidence of systemic candidiasis $(4.8 \%)$ than infants weighing $>1500 \mathrm{~g}$ $(0.2 \%)(\mathrm{p}<0.001)$. Candida albicans was the most frequent species $(52.5 \%)$, followed by C. parapsilosis $(23.7 \%)$ and C. tropicalis $(7.6 \%)$. However, they did not perform antifungal susceptibilities of these organisms.

Although the candidemic days of both newborn groups were similar, the lower antifungal susceptibilities in Group 2 could be related to longer ventilation and catheterization periods (Table 1). These longer catheterization periods were related to their primary diagnosis. Roilides et al. ${ }^{[11]}$ compared infants according to candida species rather than weight. The mean gestational ages of the infants in that study were $29.5 \pm 0.6$ weeks for C. albicans episodes and $30.9 \pm 1.1$ weeks for non-albicans episodes. The mean of candidemia days in Group 1 and 2; $19.4 \pm 2.3$ and $13.4 \pm 1.7$ days, and catheter days were $4.5 \pm 0.6$ and $4.7 \pm 0.9$ days, respectively. Due to the different design of the comparison groups, only candidemic days and catheter days could be compared with the present study. Candidemic days of both studies were similar but catheter days were longer in the present study. When the antifungal susceptibilities of both studies were compared, only the finding that $\mathrm{MIC}_{90}$ levels of non-albicans species in Group 2 in the present study were higher is similar to the findings of Roilides et al. ${ }^{[11]}$

Table 2. $\mathrm{MIC}_{50}$ and $\mathrm{MIC}_{90}$ values $(\mu \mathrm{g} / \mathrm{mL})$ of fluconazole, itraconazole, ketoconazole and $\mathrm{CAB}^{*}$ for candida strains.

\begin{tabular}{|c|c|c|c|c|c|}
\hline & \multirow[b]{2}{*}{$\begin{array}{l}\text { MIC Values } \\
\qquad(\mu \mathrm{g} / \mathrm{ml})\end{array}$} & \multicolumn{2}{|c|}{ Group 1} & \multicolumn{2}{|c|}{ Group 2} \\
\hline & & $\begin{array}{l}\text { Albicans } \\
(\mathrm{n}=15)\end{array}$ & $\begin{array}{l}\text { Non-albicans } \\
(\mathrm{n}=4)\end{array}$ & $\begin{array}{l}\text { Albicans } \\
(\mathrm{n}=22)\end{array}$ & $\begin{array}{l}\text { Non-albicans } \\
(\mathrm{n}=4)\end{array}$ \\
\hline Fluconazole & $\begin{array}{l}\mathrm{MIC}_{50} \\
\mathrm{MIC}_{90}\end{array}$ & $\begin{array}{l}0.19 \\
0.38\end{array}$ & $\begin{array}{l}0.19 \\
0.25\end{array}$ & $\begin{array}{l}0.19 \\
0.38\end{array}$ & $\begin{array}{l}0.25 \\
0.75\end{array}$ \\
\hline Itraconazole & $\begin{array}{l}\mathrm{MIC}_{50} \\
\mathrm{MIC}_{90}\end{array}$ & $\begin{array}{l}0.008 \\
0.047\end{array}$ & $\begin{array}{l}0.012 \\
0.016\end{array}$ & $\begin{array}{l}0.012 \\
0.032\end{array}$ & $\begin{array}{l}0.25 \\
0.38\end{array}$ \\
\hline Ketoconazole & $\begin{array}{l}\mathrm{MIC}_{50} \\
\mathrm{MIC}_{90}\end{array}$ & $\begin{array}{l}0.008 \\
0.012\end{array}$ & $\begin{array}{l}0.012 \\
0.032\end{array}$ & $\begin{array}{l}0.008 \\
0.023\end{array}$ & $\begin{array}{l}0.032 \\
0.032\end{array}$ \\
\hline $\mathrm{CAB}^{*}$ & $\begin{array}{l}\mathrm{MIC}_{50} \\
\mathrm{MIC}_{90}\end{array}$ & $\begin{array}{l}0.125 \\
0.38\end{array}$ & $\begin{array}{l}0.047 \\
0.38\end{array}$ & $\begin{array}{l}0.25 \\
0.5\end{array}$ & $\begin{array}{l}0.16 \\
1.00\end{array}$ \\
\hline
\end{tabular}


In a recent study, prophylactic fluconazole use in preterm infants was investigated in a multicentric, randomized fashion. ${ }^{[1]}$ Three hundred and twenty-two neonates weighing less than $1500 \mathrm{~g}$ at birth in eight tertiary Italian NICU's were randomly assigned to receive either fluconazole (at a dose of either $6 \mathrm{mg}$ or $3 \mathrm{mg}$ per kilogram of body weight) or a placebo from birth until the 30th of life. The conclusion was that prophylactic fluconazole reduced Candida colonization in these infants but the therapeutic benefit was unclear. The higher antifungal susceptibilities, namely quick response to antifungal drugs in Group 1 in the present study, support that conclusion.

Although, prophylactic fluconazole use to reduce the incidence of invasive fungal infections in VLBW infants is common, resistance to azole derivates has remained low, also in Turkey. ${ }^{[12,13]}$ In this retrospective study, prophylactic fluconazole was not used. Only non-albicans species in Group $2(n=4)$ were relatively resistant to CAB.

In conclusion, C. albicans was the most common species in both groups. All Candida isolates yielded from Group 1 were more susceptible to antifungal drugs. Minimum inhibitory concentration ${ }_{50}$ and $\mathrm{MIC}_{90}$ values of non-albicans strains were almost always higher in Group 2. Candida species were similar in both infant groups weighing $\leq 1500 \mathrm{~g}$ and $>1500 \mathrm{~g}$. However, susceptibility was less in infants weighing $>1500 \mathrm{~g}$. We believe this is related to the greater number of possible risk factors in the present patients. The present study filled the lack of data comparing susceptibility patterns of Candida isolates in candidemic newborns that weigh $\leq 1500 \mathrm{~g}$ versus those that weigh $>1500 \mathrm{~g}$.

\section{Acknowledgement}

We thank to Dr. Canan Aygün for her contribution to the study.

\section{REFERENCES}

1. Manzoni P, Stolfi I, Pugni L, Decembrino L, Magnani C, Vetrano $\mathrm{G}$, et al. A multicenter, randomized trial of prophylactic fluconazole in preterm neonates. N Engl J Med 2007;356:2483-95.

2. Nakamura T, Takahashi H. Epidemiological study of
Candida infections in blood: susceptibilities of Candida spp. to antifungal agents, and clinical features associated with the candidemia. J Infect Chemother 2006;12:132-8.

3. Huang YC, Kao HT, Lin TY, Kuo AJ. Antifungal susceptibility testing and the correlation with clinical outcome in neonatal candidemia. Am J Perinatol 2001;18:141-6.

4. López Sastre JB, Coto Cotallo GD, Fernández Colomer B; Grupo de Hospitales Castrillo. Neonatal invasive candidiasis: a prospective multicenter study of 118 cases. Am J Perinatol 2003;20:153-63.

5. Huang YC, Lin TY, Lien RI, Chou YH, Kuo CY, Yang PH, et al. Fluconazole therapy in neonatal candidemia. Am J Perinatol 2000;17:411-5.

6. Juster-Reicher A, Leibovitz E, Linder N, Amitay M, FlidelRimon O, Even-Tov S, et al. Liposomal amphotericin B (AmBisome) in the treatment of neonatal candidiasis in very low birth weight infants. Infection 2000;28:223-6.

7. Espinel-Ingroff AV, Pfaller MA. Susceptibility test methods: yeasts and filamentous fungi. In: Murray PR, Baron EJ, Jorgensen JH, Pfaller MA, Yolken RH, editors. Manual of Clinical Microbiology. 8th ed. Washington DC: American Society Microbiology; 2003. p. 1880-94.

8. Rex JH, editor. Reference method for broth dilution antifungal susceptibility testing of yeasts: approved standard. 3rd ed. Pennsylvania: Clinical and Laboratory Standards Institute; 2008.

9. Pfaller MA, Jones RN, Doern GV, Sader HS, Hollis RJ, Messer SA. International surveillance of bloodstream infections due to Candida species: frequency of occurrence and antifungal susceptibilities of isolates collected in 1997 in the United States, Canada, and South America for the SENTRY Program. The SENTRY Participant Group. J Clin Microbiol 1998;36:1886-9.

10. Kovacicova G, Krupova Y, Lovaszova M, Roidova A, Trupl J, Liskova A, et al. Antifungal susceptibility of 262 bloodstream yeast isolates from a mixed cancer and non-cancer patient population: is there a correlation between in-vitro resistance to fluconazole and the outcome of fungemia? J Infect Chemother 2000;6:216-21.

11. Roilides E, Farmaki E, Evdoridou J, Dotis J, Hatziioannidis E, Tsivitanidou $\mathrm{M}$, et al. Neonatal candidiasis: analysis of epidemiology, drug susceptibility, and molecular typing of causative isolates. Eur J Clin Microbiol Infect Dis 2004;23:745-50.

12. Clerihew L, Austin N, McGuire W. Systemic antifungal prophylaxis for very low birthweight infants: a systematic review. Arch Dis Child Fetal Neonatal Ed 2008;93:F198-200.

13. Bilgen H, Özek E, Ülger N, Çerikcioğlu N, Söyletir G. Neonatal candida infections in an intensive care unit: a three year experience. Marmara Medical Journal 2000;13:201-4. 